DOI: $10.17516 / 1997-1397-2020-13-4-451-458$

УДК 537.622.4

\title{
Structural Changes of Co Caused a Change of the Solution pH During Chemical Deposition
}

\author{
Sergey A. Podorozhnyak* \\ Siberian Federal University \\ Krasnoyarsk, Russian Federation
}

Anatoly V. Chzhan ${ }^{\dagger}$

Siberian Federal University

Krasnoyarsk, Russian Federation

Krasnoyarsk State Agrarian University

Krasnoyarsk, Russian Federation

Vadim K. Maltsev ${ }^{\ddagger}$

Ivan N. Krayuhin ${ }^{\S}$

Siberian Federal University

Krasnoyarsk, Russian Federation

Gennady S. Patrin

Siberian Federal University

Krasnoyarsk, Russian Federation

Kirensky Institute of Physics FIC KNC SB of the RAS,

Krasnoyarsk, Russian Federation

Irina Yu. Sakash

Krasnoyarsk State Agrarian University

Krasnoyarsk, Russian Federation

Received 10.04.2020, received in revised form 13.05.2020, accepted 25.06.2020

\begin{abstract}
The phase transformations of the Co lattice are discussed, which determine the anomalous changes in the magnetic properties of chemically deposited Co-P films obtained at various $\mathrm{pH}$ values. The coercivity of the $\mathrm{H}_{\mathrm{c}}$ films obtained at low $\mathrm{pH}$ values exceeds $1 \mathrm{kOe}$ and decreases to several units Oe in the films obtained at high $\mathrm{pH}$ values. It is shown that the observed changes in the magnetic properties of Co-P films are caused by the transition of the cobalt crystal lattice to the nanocrystalline state.
\end{abstract}

Keywords: Co-P films, chemical reduction of metals, induced magnetic anisotropy, nanocrystalline material.

Citation: S.A. Podorozhnyak, A.V. Chzhan, V.K. Maltsev, I.N. Krayuhin, G.S. Patrin, I.Yu. Sakash, Structural Changes of Co Caused a Change of the Solution pH During Chemical Deposition, J. Sib. Fed. Univ. Math. Phys., 2020, 13(4), 451-458. DOI: 10.17516/1997-1397-2020-13-4-451-458.

The most famous and broadly used technology of metal's chemical deposition from salt solutions is the application of anticorrosion coating upon metallic surfaces, as well as producing the connecting stripes on printed-circuit boards for the needs of radio electronics. Besides

\footnotetext{
*srodinger@mail.ru https://orcid.org/0000-0002-9885-181X

†avchza@mail.ru

‡vkmal@mail.ru

§Krayuhin@mail.ru

ฯpatrin@iph.krasn.ru

(C) Siberian Federal University. All rights reserved
} 
these industries, using the chemical technology is very perspective for the purposes of producing thin magnetic films which are necessary for developing such devices as memory cells for magnetic/thermomagnetic recording and data storage, as well as creating highly sensitive signal transmitters. The most interesting, from an applied science's point of view, is a possibility of producing materials with various characteristics that is easily performed by changing conditions of chemical reactions, such as chemical composition and acidity of the deposition's environment, a temperature of the deposition and so on. There upon, the magnetic films produced by Co-P alloying are especially interesting. This alloy, because of high values of some cobalt parameters, is most usable in terms of practical application. Therefore, the specificity of its producing is a subject of scientific interest that resulted in a number of publications. The most of them are focused on the influence of solution acidity upon the films' structural and magnetic properties. Using some additional reagents, able to change solutions' $\mathrm{pH}$, it is possible to improve the morphology of film's surface, to change its structure [1-5] and to produce, depending on the $\mathrm{pH}$ value, either highcoercivity or lowcoercivity specimens [6-8]. However, because of the experiment's multi centricity and the complexity of describing the redox processes, the technology of metals' chemical deposition from water solutions is not properly studied and developed. This is the main factor barring broad use of chemical deposition for the purposes of producing magnetic films.

This work, based upon experimental data, demonstrates that, within the given range of the process solution's concentrations, growth of the solution's $\mathrm{pH}$ follows to a polymorphic phase transition of the Co crystal lattice from the $h c p$ structure to the $f c c$ one, that results in anomalous changes of its magnetic properties: coercive force and magnetic anisotropy. Basing on the analysis of redox processes of the cobalt deposition, the procedure of revealing the $\mathrm{pH}$ influence upon the granular microstructure is proposed.

\section{The technology of specimen producing and the procedure of measurement}

The process solution is the water one of cobalt sulphate $\left(\mathrm{CoSO}_{4} \cdot 7 \mathrm{H}_{2} \mathrm{O}\right)$ with the concentration of $15 \mathrm{~g} / \mathrm{l}$, the solution of sodium hypophosphite $\left(\mathrm{NaH}_{2} \mathrm{PO}_{2} \cdot \mathrm{H}_{2} \mathrm{O}\right)$ of $10 \mathrm{~g} / \mathrm{l}$, and the one of sodium citrate $\left(\mathrm{Na}_{3} \mathrm{C}_{6} \mathrm{H}_{5} \mathrm{O}_{7}\right)$ of $25 \mathrm{~g} / \mathrm{l}$. The required $\mathrm{pH}$ value is reached by adding alkaline reagents such as sodium hydro carbonate $\mathrm{NaHCO}_{3}$ or caustic soda $\mathrm{NaOH}$ of different concentrations. The value of solutions' acidity is measured by the $\mathrm{pH}-150 \mathrm{MI}$ apparatus to an accuracy of \pm 0.05 . The deposition goes under the temperature of $100^{\circ} \mathrm{C}$ and the magnetic-field strength of $\mathrm{H}=3 \mathrm{kOe}$ on a cover glass faceplate, previously cleaned, sensitized and activated by the methods, standard for the technology of dielectrics' chemical metallization.

The films' microstructure is analyzed by the methods of transmission electron microscopy, including revealing the specimens' elemental composition, using a TEM HT-7700 (Hitachi) with a X-Flash 6T/60 (Bruker) energy dispersive detector. The values of coercive force and saturation intensity are revealed by, consequently, the meridional Kerr effect and a SQUID magnetometer (room temperature). Measuring NMR-signals is performed by a standard spin echo apparatus within the range of $150-250 \mathrm{MHz}$.

\section{Research results}

Fig. 1 shows dependence of the created films' induced anisotropy constant $\mathrm{K}_{\mathrm{U}}$ and the coercivity $\mathrm{H}_{\mathrm{C}}$ upon solutions' acidity. 


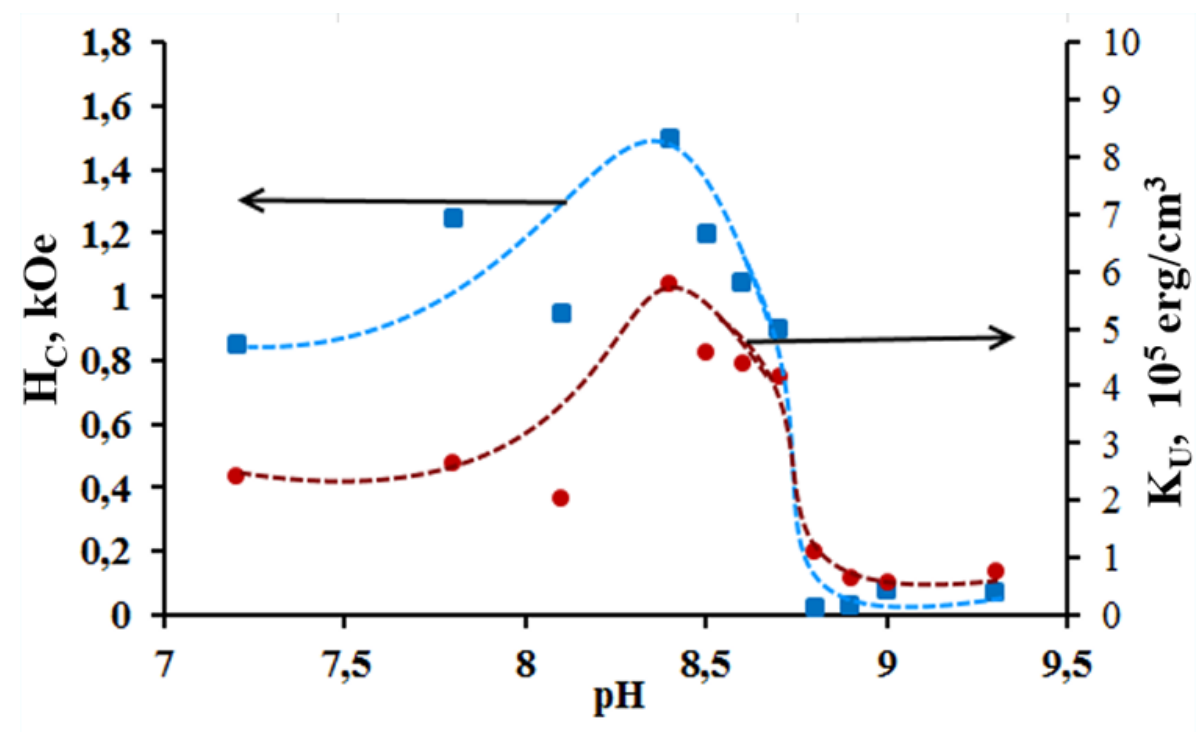

Fig. 1. Dependence of $\mathrm{H}_{\mathrm{C}}$ and $\mathrm{K}_{\mathrm{U}}$ on the solution's acidity

Within the range of low $\mathrm{pH}(7.2 \div 8.5) \mathrm{K}_{\mathrm{U}}$ value is $\sim 2.5 \times 10^{5} \mathrm{erg} / \mathrm{cm}^{3}$. Growing $\mathrm{pH}$ follows to rising anisotropy, and within the range of $\mathrm{pH} \sim 8.5 \mathrm{~K}_{\mathrm{U}}$ is $\sim 6 \times 10^{5} \mathrm{erg} / \mathrm{cm}^{3}$. The following growth of acidity results in a step-like drop of $\mathrm{K}_{\mathrm{U}}$ by an order, to $5 \times 10^{4} \mathrm{erg} / \mathrm{cm}^{3}$. The value of $\mathrm{H}_{\mathrm{C}}$ with $\mathrm{pH}$ growing to $\sim 8.5$ rises from $\sim 1 \mathrm{kOe}$ to $\sim 1.5 \mathrm{kOe}$, and later, with the following $\mathrm{pH}$ growth, $\mathrm{H}_{\mathrm{C}}$ step-likely drops down to few Oes.

As it follows from the data of specimens' X-ray diffraction analysis, obtained for $\mathrm{pH}<8.5$ (Fig. 2a), the highly coercivity is characterized by existing a $h c p$-phase of cobalt. Relatively equal heights of major peaks reflect presence of the polycrystalline structure with no preferred direction of the crystallite growth; that may also be derived from the analysis of electron microscopic (TEM) micrographs of the surfaces, represented by Fig. 2b. Fig. 2c demonstrates a typical electron diffraction pattern of a highcoercive polycrystalline film.

The transition to lowly coercive conditions with $\mathrm{pH}>8.5$ corresponds with the film structure changes, visible at transmission electron microscopic (TEM) micrographs of the surface, represented by Fig. 3b. X-ray photographs of such specimens show diffused reflexes, typical for nanocrystalline materials (Fig. 3a). Layers, dividing denser structural formations, are visible at TEM micrographs as well as it is in the case of highly coercive Co-P films. These electron diffraction patterns (Fig. 3c) bear witness to the presence of a nanocrystalline structure.

Basing on the analysis of TEM micrographs of the highly anisotropic polycrystalline films and electron diffraction patterns of the lowly anisotropic polycrystalline ones, the dependence of the size of granules (of which the films consist) on $\mathrm{pH}$ values is revealed (Fig. 4).

Because the X-ray diffraction analysis is poor for obtaining data on the Co atomic environment in the films with small grains the spin echo NMR method has been used for these purposes [9]. It is well-known that the amplitude of the spin echo NMR signal is determined by the specimen's magnetic susceptibility $\chi$, that is inversely proportional to the value of the magnetic anisotropy's field $\left(\mathrm{A}_{\mathrm{e}} \sim 1 / \mathrm{H}\right)$. Thus the NMR technology has been used for researching lowly anisotropic specimens. The integral spin echo spectrum of the studied specimens is a broad curve (within the range of $185-230 \mathrm{MHz}$ ) having a diffused maximum, located near $200 \mathrm{MHz}$, the signal intensiveness dropping to zero at the low-frequency left part of the curve and, at the same time, 

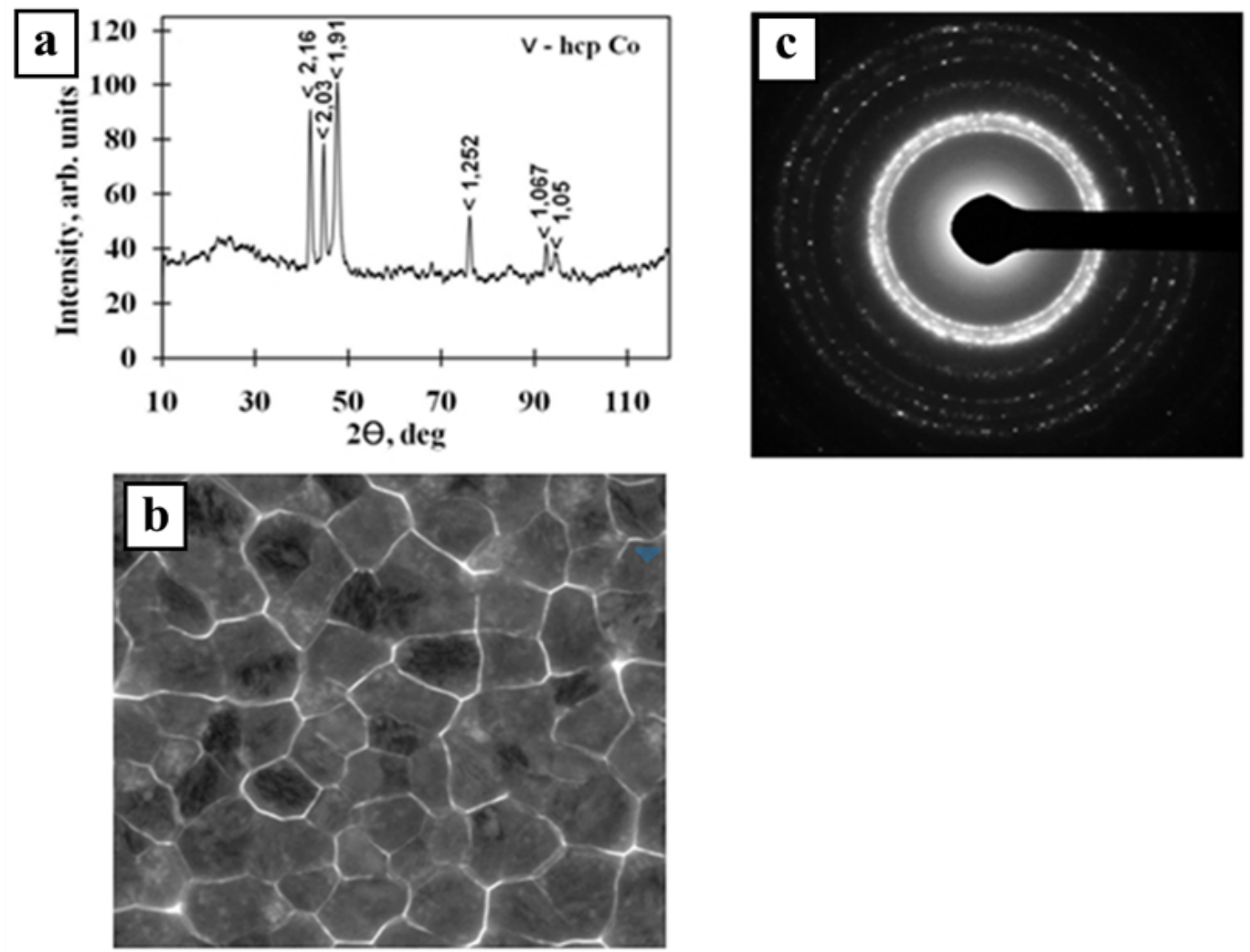

Fig. 2. Research data on the highly anisotropic specimens: a - roentgenogram, b - electron microscopic (TEM) micrograph, c - electron diffraction pattern

certain absorption features at the right part of the spectrum (Fig. 5). This absorption maximum corresponds with incomplete filling of the first coordination sphere (11 instead of 12) in the nearest environment of Co atoms within close packing of the $f c c$-phase. This effect may be a result of cobalt lattice defects, diamagnetic substitution of a cobalt atom by one of phosphorus, edge (surface) effects and uncompensated ties on the surface of crystallites. Additional absorption maxima (216 MHz and $227 \mathrm{MHz}$ ) correspond to the high-frequency absorption of Co nuclei for $f c c$ and $h c p$ structures consequently. This peak looks more intensive for the A-specimen and more diffused for the $\mathrm{B}$ one, that is caused by a greater degree of disordering within the nearest atomic environment of the $f c c$ lattice. There is an additional peak $(227 \mathrm{MHz})$ for the B-specimen that corresponds with the influence of the $h c p$ lattice.

\section{Discussion}

It is well-known that there is close interrelation between the cobalt particles' sizes and their crystal structure. Small particles $(\mathrm{d}<10 \mathrm{~nm})$ have cubic $f c c$ structure $(\beta$-phase), whereas large ones $(\mathrm{d}>40 \mathrm{~nm})$ have $h c p$ structure ( $\alpha$-phase); the intermediary field has a mixture of both [10]. Such transformations of crystal structures are caused by a various degree of dependence of the $\alpha$ - and $\beta$-phase free energy on cobalt particles' diameters. The structural changes of cobalt 

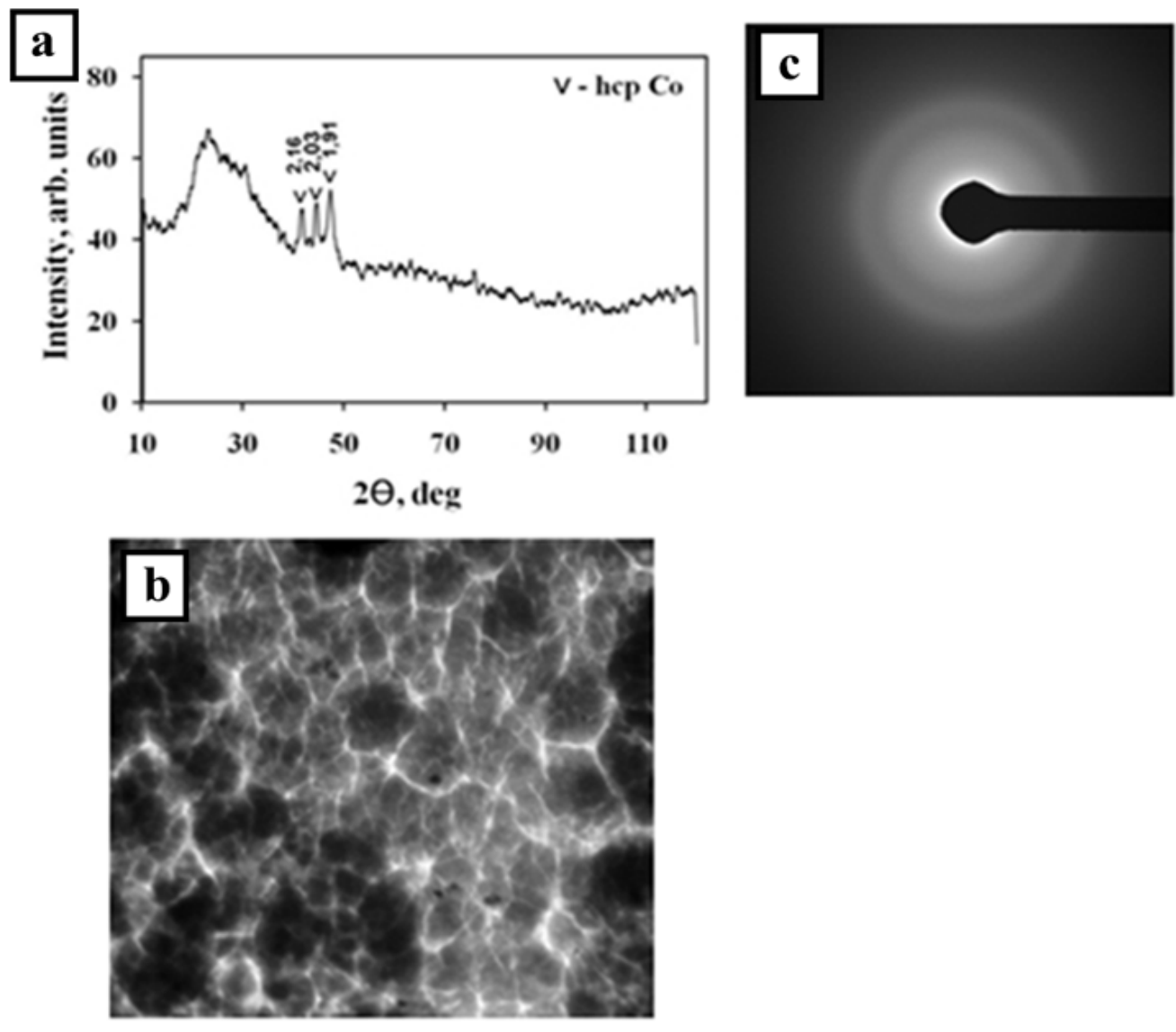

Fig. 3. Research data on the lowly anisotropic specimens a - roentgenogram, b - electron microscopic (TEM) micrograph, c - electron diffraction pattern

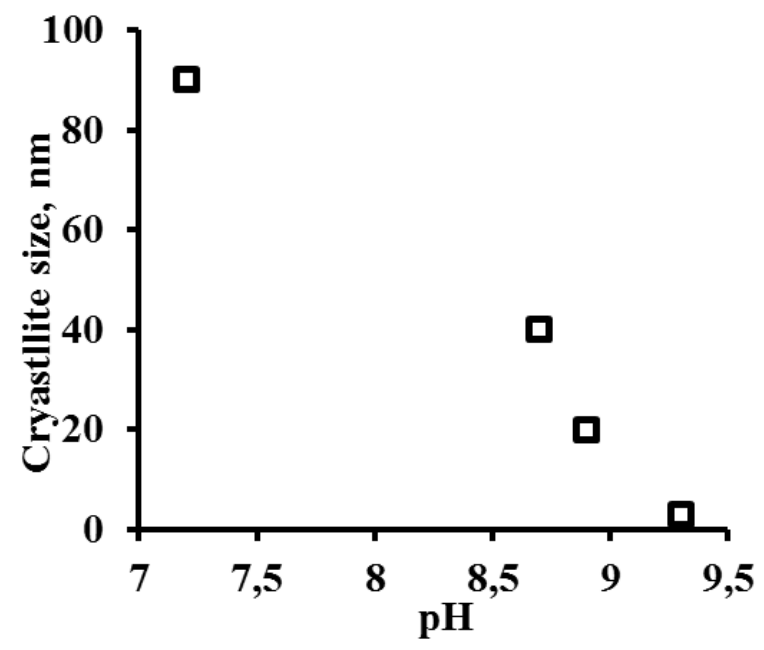

Fig. 4. Dependence of crystallites sizes on solution's pH 

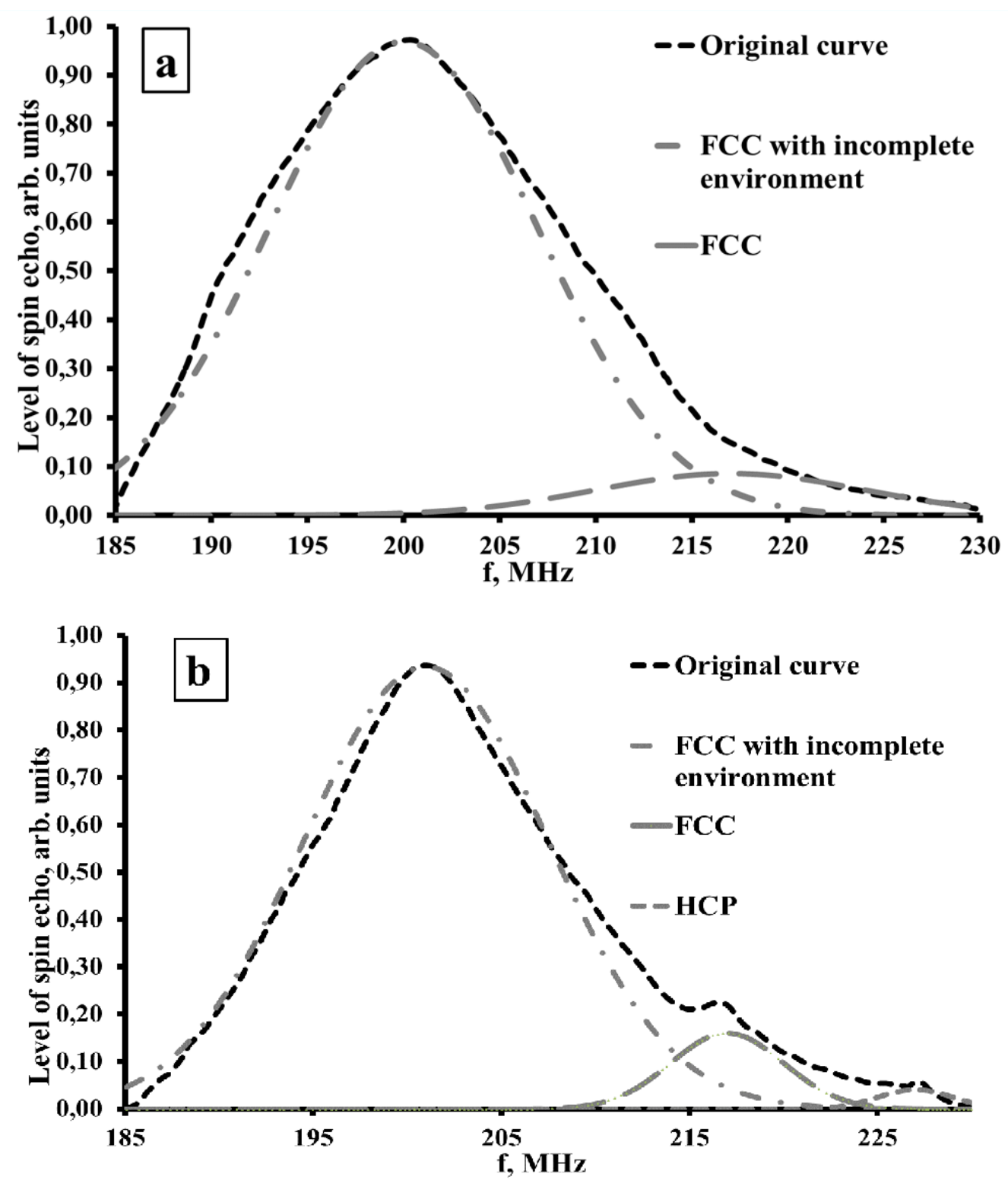

Fig. 5. Spectrum of spin echo specimens, created by $\mathrm{pH}=8.9$ (a) and 9.15 (b)

particles correspond with visible structural variations of the films studied. If $\mathrm{pH}$ is low, large Co particles emerge (up to $70 \mathrm{~nm}$ ); their stable phase is $\alpha$-phase. Growing acidity results in the emergence of smaller Co particles (up to $5 \mathrm{~nm}$ ) whose stable phase is $\beta$-phase. As it follows from the aforementioned data, the films, created within the environment with low $\mathrm{pH}$ values, mostly have the $h c p$ structure with large crystallites; the latter are diminishing together with growing acidity and, if $\mathrm{pH}$ becomes more than 8.5 , the structure of the substance is becoming transformed into the $f c c$-modification. In the beginning of this transformation we can see a mixture of the phases with the dominated influence of $h c p$-cobalt upon magnetic properties of the substance. The phase transition ends at $\mathrm{pH} \approx 8.7$ when the substance's magnetic properties become to be determined by cobalt's $\beta$-phase. This transition is diffused because of sufficient dispersion of 
the particles' sizes in the films that results in their phase heterogeneity. The following acidity growth leads to subsequent depressing $\alpha$-phase of cobalt; the substance mostly transforms into a $f c c$ lattice with an incomplete environment.

\section{Conclusion}

As it follows from the data obtained, sharp changes of the induced magnetic anisotropy and the coercive force of Co-P films in the conditions of growing acidity correspond with Co crystal lattice's modifications. The films, created in the environment with low $\mathrm{pH}$, have a structure with large Co crystallites of $h c p$ lattice. The acidity growth leads to decrease of the crystallites' typical sizes and, as a result, to the polymorphic phase transition with emerging $f c c$ structure.

We are grateful to the Center for the common use of Federal Research Center KSC SB RAS.

\section{References}

[1] A.Brenner, G.Riddell, Deposition of Nickel and Cobalt by Chemical Reduction, J. Res. Nat., 37(1947), no. 31, 385-395.

[2] G.A.Jones, M.Aspland, Some aspects of the growth and structure of electroless deposited films, Phys. Stat. Sol.(a), 11(1972), 637-644.

[3] A.W.Simpson, D.R.Brambley, The Magnetic and Structiiral Propertiesof Bulk Amorphous and Crystalline Co-P Alloys, Phys. Stat. Sol.(b), 43(1971), 291-300.

[4] U.Admon, A.Bar-Or, D.Treves, Microstructure of Cobalt and Cobalt-Phosphorous Thin Films, J. Appl. Phys., 44(1973), 2300-2303.

[5] L.Nianduan, C.Jian, L.Liangliang, Dependence of interfacial adhesion of Co-P film on its microstructure, Surface \& Coatings Technology, 206(2012), no. 23, 4822-4827.

[6] M.Aspland, G.A.Jones, B.K.Middleton, Properties of Electroless Cobalt Films, IEEE Trans. On Magn. MAG-5, 1969, 314-317.

[7] A.V.Chzhan, S.A.Podorozhnyak, G.N.Bondarenko, M.N.Volochaev, G.S.Patrin, Physics of the Solid State, 59(2017), no. 7, 1440-1445. DOI: 10.1134/S1063783417070058

[8] H.Wang, Z.Du, L.Wang, G.Yu, F.Zhu, Preparation and magnetic properties of Co-P thin films, Journal of University of Science and Technology Beijing, 5(2008), 618-621.

[9] V.K.Maltsev, G.I.Fish, V.I.Tsifrinovich, Jump-like change in the spectrum of nuclear magnetic resonance upon heating of the amorphous Co-P compound, The Physics of Metals and Metallography, 52(1981), no. 2, 439-441.

[10] O.Kitakami, H.Sato, Y.Shimada, F.Sato, M.Tanaka, Size effect on the crystal phase of cobalt fine particles, Phys. Rev. B, 56(1997), no. 21, 13849-13854. 


\title{
Структурные изменения кобальта, вызванные изменением рН при химическом осаждении
}

Сергей А. Подорожняк

Сибирский федеральный университет

Красноярск, Российская Федерация

Анатолий В. Чжан

Сибирский федеральный университет

Красноярск, Российская Федерация

Красноярский государственный аграрный университет

Красноярск, Российская Федерация

Вадим К. Мальцев

Иван Н. Краюхин

Сибирский федеральный университет

Красноярск, Российская Федерация

Геннадий С. Патрин

Сибирский федеральный университет

Красноярск, Российская Федерация

Институт физики им. Киренского, ФИЦ КНЦ СО РАН

Красноярск, Российская Федерация

Ирина Ю. Сакаш

Красноярский государственный аграрный университет

Красноярск, Российская Федерация

\begin{abstract}
Аннотация. Обсуждаются фазовые превращения решетки Со, которые определяют аномальные изменения магнитных свойств химически осажденных пленок Сo-Р, полученных при различных значениях рН. Коэрцитивная сила пленок, полученных при низких значениях рН, превышает 1 кЭ и снижается до нескольких единиц Э в пленках, полученных при высоких значениях рН. Показано, что наблюдаемые изменения магнитных свойств пленок Со-Р вызваны переходом кристаллической решетки кобальта в нанокристаллическое состояние.
\end{abstract}

Ключевые слова: пленки Со-Р, химическое восстановление металлов, наведенная магнитная анизотропия, нанокристаллический материал. 